Zagadnienia Rodzajów Literackich, LXI, z. 1

PL ISSN 0084-4446

DOI: https://doi.org/10.26485/ZRL/2018/61.1/3

Barbara Niebelska-Rajca

Katolicki Uniwersytet Lubelski Jana Pawła II*

\title{
The Poetics of Phantasia: Some Remarks on the Renaissance Concepts of Imagination and "Fantastic Imitation"
}

\begin{abstract}
According to the traditional view, the notion of imagination in early modern aesthetics was a rather marginal and subsidiary concept within the classical doctrine of mimesis dominated by rules and reason. The present paper raises some doubts about this wellestablished opinion. It argues that even if imagination in early modern aesthetics did not play as prominent role as in Romantic poetics, the concept had significant relevance. It presents one important episode from the Renaissance debate on imagination, which arose from the sixteenth century literary quarrel over the artistic quality and the uncertain genre of Dante's Commedia. Its main distinctive category was "fantastic imitation" - a concept derived from Plato, yet misunderstood and thus transformed.
\end{abstract}


* Instytut Filologii Polskiej, Wydział Nauk Humanistycznych Katolickiego Uniwersytetu Lubelskiego Jana Pawła II al. Racławickie 14, 20-950 Lublin e-mail: niebelska@icloud.com 
la phantasia è la propria potenza delle favole poetiche.

(Mazzoni 2017: 547)

In his famous 1966 essay Jalons pour une histoire du concept d'imagination, Jean Starobinski asked a vital question: should scholars be content with the stereotypically strong contrast between the hegemony of reason in early modern literature and the flourishing of imagination in Romanticism? (Starobinski 1970). Despite the considerable time that has passed since Starobinski's observations, the thought-scheme he pointed out seems to remain valid. It is still quite common to contrast the Romantic creative imagination, liberated from the restrictions of reason, and the latter's dominance in the old-fashioned doctrine of imitation. According to this, the late $18^{\text {th }}$-century 'discovery' of imagination is to be valued higher than the humble cluster of concepts, i.e. invention, ingenium or wit, and finally phantasia-imaginatio ${ }^{1}$, which were used to describe the nature of artistic imitation in classical aesthetics.

In recent decades, Renaissance scholars have attempted to prove that the notion of phantasia-imaginatio had significant relevance in early modern aesthetics, and was closer to the idea of 'creativity' than previously assumed (cf. Kemp 1977; Faivre 1981; Cocking 1991; Wels 2005; Chevrolet 2007; Giglioni 2010). However, these attempts are still not sufficiently widespread and few in number compared to the numerous studies on the category of imagination in philosophy ${ }^{2}$. This shows how strong the silent assumption is that phantasia-imaginatio is nothing more than a marginal, merely subsidiary concept within the early modern aesthetics of mimesis. If this were the case, it certainly seems less attractive than imagination in early modern philosophy — understood as a faculty of the

1 The term phantasia-imaginatio that links together both the Greek version and its Latin equivalent is well established in scholarship. It appears for instance as the title of the volume of studies on the philosophy of imagination, cf. Phantasia-imaginatio 1988. However, terms phantasia and imaginatio in medieval and early modern philosophy were used to describe different capacities of the soul - so-called internal senses (cf. Wolfson 1973: 250-314), in early modern aesthetics both terms were usually designating the capacity responsible for 'making images'. For this reason, in the general introduction to this paper, I often use the form phantasia-imaginatio rather than two separate classical terms or their modern equivalents.

2 I would like to mention here at least three valuable volumes on the imagination in philosophy, which have been published in recent decades: Phantasia-imaginatio 1988; 'Imago in phantasia depicta' 1999; De la phantasia à l'imagination 2003. 
soul or one of the internal senses participating in the process of acquiring knowledge. Moreover, Renaissance phantasia-imaginatio may appear less impressive than, for instance, Coleridge's famous distinction between passive fantasy and vital imagination (Coleridge 1834: 172-173) and less striking than Wordsworth's imagination defined as "Reason in her most exalted mood" (Wordsworth 1850: 361).

What should not be neglected in this context is an obvious fact that the Romantic poetics shaped our modern thinking about the creative power of imagination. Being aware of that, we need, therefore, to be very careful while confronting theories of the past with Romantic or modern assumptions about imagination. Doing otherwise might cause a misunderstanding that could arise from overlapping the early modern concept with the essentially modern meanings. In classical studies on the ancient concept of phantasia, scholars occasionally resolve this issue in a very radical manner by completely abandoning the standard translation of the Greek term phantasia as 'imagination' ${ }^{3}$. In a study on early modern aesthetics, it is neither necessary nor possible, because both terms, inherited from Greek and Roman Antiquity, i.e. phantasia and imaginatio, were almost interchangeably used in Renaissance treatises (with some marginal exceptions). Moreover, the meanings of 'imagination' in some of the late Renaissance poetics, which appreciated its image-making, unifying and even 'transformative' powers, were not extremely distant from some of the early Romantic assumptions. But even if certain similarities are evident, in order to avoid imposing modern assumptions on the Renaissance theories, caution is required in any attempt to confront these terms. A complete comparison between the late Renaissance and the Romantic aesthetic theory of the imagination — though possible and undoubtedly needed — should be considered within the broad context of sixteenth-eighteenth century philosophical debates over the concept of imagination, and such a complex endeavour exceeds the modest ambitions of the present brief essay. What will be emphasised below is the importance of the question of phantasia-imaginatio, particularly vital in aesthetic thought at the end of the sixteenth century, with some fragments of late Renaissance poetics, which can easily disprove the traditional assumption about the marginal function of imagination in early modern aesthetics.

There exists a certain affinity between ancient and early modern aesthetic notions of phantasia, which can shed light on one of the differences between the Renaissance and the eighteenth century view of imagination. Both the Renaissance and the Romantic imagination involve so-called mental images. However, the Romantic way of thinking about imagination and mental images implies that "the mind projects its images outward onto the world, functioning like a lamp rather than a mirror", as Anne Sheppard has recently emphasized, quoting M.H. Abram's famous contrast from The Mirror and the Lamp, and concluding that "ancient poetics is predominantly the poetics of the mirror rather than the lamp" (Sheppard 2014: 2). This principle applies to some extent to the Renaissance poetics of phantasia-imaginatio. Since Marsilio Ficino's commentaries to Plato's dialogues (cf. e.g. Ficino 1987: 124), the imaginative power (vis imaginativa) was compared by Renaissance thinkers to a mirror that reflects images received from sense perception or — in the theories inspired by Neoplatonic thought — visions from the intelligible world. We come across such definitions of mirror-like phantasia, crystal-like or glass-like imagination in

3 Cf. e.g. Modrak 1986. For a detailed discussion on the concepts phantasia and imaginatio in ancient thought cf. Sheppard 2014; Manieri 1998; Watson1988; Rispoli 1985; Armisen 1979; 1980. 
treatises by Bernardino Tomitano, Torquato Tasso, Pierre de Primaudaye, George Puttenham, and others (cf. Tomitano 1570: 419r; La Primaudaye 1580: 93; Tasso 1964: 91; 1859: 230; Puttenham 2007; 108-109).

However, this does not mean that Renaissance theory excludes creative functions of phantasia-imaginatio; beside the mirror analogy, the figures of Proteus and chameleon are also used to describe the productive and combinatory capacities of imagination. "Imaginatio est tamquam Proteus vel Cameleon" - Ficino writes when he is explaining the cooperation between imagination and sense perception (Ficino 1576: 1825). In the following century Alessandro Lionardi, a theorist of poetic invention, though he does not use the term imagination, equates the poet's creative and inventive vigor with the figure of Proteus, who is able to transform himself into any thing or any person he wishes (Lionardi 1554: 63).

Lionardi's statement reveals a characteristic, well-known feature of the Renaissance mode of explaining the nature of the artist's creativity, which often omits the terms "imagination" or "fantasy" and satisfies itself with the concept of invention - not always explicitly linked with the faculty of imagination. Pierre de Ronsard's interpretation of the invention as "a natural gift of imagination" ("le bon naturel d'une imagination") (Ronsard 1870: 408) is an exception rather than a rule among the standard Renaissance definitions of poetic invention. Sidney's famous proclamation about the liberty of the poet's creation "within the zodiac of his own wit" (Sidney 2002: 85) displays similar tendency. Sidney does not mention the term imagination in this passage, but his figure of the poet "lifted up with the vigour of his own invention" who creates imaginary beings, non-existent in the external realm of reality (like Cyclops, Chimeras etc.), can be easily compared with many of the Renaissance explanations of phantasia-imaginatio as a faculty that conjures up fantastic creatures and images.

Much of the material to be discussed in the next part of this paper belongs to the late Renaissance line of aesthetic thought, in which the concept of imagination appears explicitly and has great relevance. A detailed presentation of the entire Renaissance debate on imagination is outside the scope of this essay, so I will focus only on one of its 'episodes': on the discussion that emerged from a sixteenth century controversy over the artistic quality and the uncertain genre of Dante's Commedia. Almost all theories described below are indebted to Plato's Sophist, and in particular to the Platonic division of "image-making art" (eidolopoiike techne) into "likeness-making art" (eikastike techne) and "fantastic art" (phantastike techne) (Sophist 235D-236D). But most of them, although they use Plato's concepts, remain very distant from the philosopher's original thought and draw on a distorted interpretation of the notion of the so-called fantastic imitation. On the other hand, the same theories, which use Plato's concepts to establish the role of imagination within the doctrine of mimesis are deeply entrenched in Aristotle's Poetics. Both traditions, Platonic and Aristotelian, reinterpreted and intermingled, constitute the late Renaissance theory of imagination and are equally important in a long and heated literary quarrel over Dante's Commedia.

The starting point of the debate remains a mystery. It was sparked in 1572 by a much circulated manuscript entitled Discorso... nel quale si dimostra l'imperfettione della "Comedia" di Dante - a brief treatise written by an anonymous author, disguised under the pseudonym 
Anselmo (or in some versions Ridolfo) Castravilla ${ }^{4}$. He started the quarrel and then disappeared, never to intervene in later polemics. He did without a doubt, however, provoke one of the most important theoretical discussions of the late cinquecento. Castravilla's virulent and impertinent attack on Commedia reveals a strongly orthodox — and in some respects (especially from a modern perspective) naïve - Aristotelianism. Its argumentation scheme is clear and simple — by juxtaposing the Commedia's structure with literally and dogmatically understood Aristotelian rules from the Poetics, Castravilla proves the alleged existence of Dante's errors, imperfections and deficiencies: lack of action and lack of plot, absence of unity and clarity, lack of verisimilitude, etc. Finally, he argues that Dante's work cannot be called a poem as it is merely a narration of a dream ("sogno raccontato") rather than an imitation of action (Castravilla 1608: 205-215).

For Castravilla's adversaries, his uncompromising dogmatism opened an excellent opportunity to reinterpret many of the crucial aesthetic and poetic concepts, such as imitation, fiction, probability, credibility, poetic truth and falsehood, and last but not least imagination and fantasy. At the same time, it led the sixteenth century critics to raise some doubts about Aristotle's Poetics as a universal instrument for evaluating poetry. The skepticism regarding the usefulness of the Poetics' rules was expressed immediately and vividly in the Florentine Accademia degli Alterati (cf. Weinberg 1961: 837-842). But the most exceptional, innovative and even 'vanguard' theory of poetry, springing from Castravilla's dogmatism, was formulated by the Cesenese philosopher Jacopo Mazzoni.

Shortly after the appearance of Castravilla's manuscript, a copy was sent to Mazzoni from Florence by Tarquinio Venturelli, who asked for an apologetic response. So in 1572, Mazzoni published his first objection against the attack on Dante: a short discourse entitled Discorso in difesa della Comedia di Dante. His later massive treatise Della difesa della Comedia di Dante was printed fifteen years later in Cesena as a polemic with Belissario Bulgarini's Alcune considerationi sopra' l' Discorso di M. Jacopo Mazzoni (1583). The second part of Difesa, with four additional books, was published posthumously a hundred years later. It is hard to precisely define the reasons that inspired Mazzoni's reaction against Castravilla's manuscript, and then his elaborate rejection of Bulgarini's arguments. Was it only his admiration for Dante's poetic achievements and a wish to correct the theorists' unjust interpretations, which made the philosopher devote more than a thousand pages to literary theory? Or was it his ambition to formulate a new, eclectic theory of poetry, based on a synthesis of Platonic and Aristotelian concepts?

As a result of his aspirations, Mazzoni created a monumental, erudite treatise, described by Italian scholars as enciclopedia letteraria ${ }^{5}$. The question of imagination constitutes an important part of its argumentation constructed diligently in order to refute Castravilla's and Bulgarini's claim that Commedia is not imitation, but only a narration of a dream. Mazzoni

4 Despite several modern hypotheses according to which the pseudonym Castravilla disguised the identity of such persons as Girolamo Muzio, Ortensio Lando, Belissario Bulgarini (a prolific participant of the discussion) or Leonardo Salviati, the identity of the author is still unknown. For a further description of the course of the quarrel over Dante, cf.: Weinberg 1961: 99-1073.

5 Despite the existing scholarship (cf. e.g. Scarpati 1985; 2002; Gigante 2001; 2003; Moreschini 2016; as well as less detailed statements by Weinberg 1961; Hathaway 1962; Chevrolet 2007; Giglioni 2010), Mazzoni’s monumental poetics still requires detailed studies. The critical edition of the first book of Difesa was published in 2017, cf. Jacopo Mazzoni, Della difesa della Comedia di Dante, a cura di Claudio Moreschini e Luigia Businarolo, Società di Studi Romagnoli, Cesena. 
devotes a large part of Difesa (book I, chap. 43-70) to the long history and various meanings of the concept of phantasia, trying to provide an unquestionable foundation for an accurate interpretation of Dante's words from the final canto of Paradiso: 'A l'alta fantasia qui mancò possa' (XXXIII, 142). According to Castravilla and Belissario Bulgarini, these words testify to the fact that the whole Commedia is nothing more than a 'narration of a dream' ("narrazion d'un sogno") because the term fantasia should be understood here as "dream". To prove this thesis, Bulgarini refers to Quintilian's well-known definition from Institutio oratoria of phantasia as visio (VI 2, 29), challenging Mazzoni's conviction that Dante's word fantasia means concetto poetico (Bulgarini 1583: 33).

Mazzoni, on the contrary, argues that phantasia is an equivocal term and as such cannot be interpreted in one way, i.e. only as dream. Dante's critics, writes Mazzoni, neglect the fact that the concept has at least four meanings and can indicate: 1) "a faculty of the soul" ("potenza dell'anima”); 2) "a form of this faculty" ("forma della sudetta potenza"); 3) "an image imprinted on it" ("specie, che s'imprime in quella"); 4) an emotion caused by appearances or dreams (Mazzoni 2017: 437). Then, he analyzes ancient and medieval philosophical theories of phantasia, especially those from Platonic and Peripatetic traditions. He is well-prepared for this kind of a task as the author of a treatise on moral philosophy (De triplici hominum vita, activa nempe, contemplativa \& religiosa methodi tres, 1577), where phantasia as a faculty of the soul is well described. He approaches the question of the relation between the intellect ("intelletto") and phantasia, the condition of phantasmata, but in Difesa he investigates also the meanings of the word phantasia in Tuscan poetry to conclude that the concept can be understood as an image/imagination generated by an exterior object and at the same time as internal concetto poetico. Dante's usage of the term in the final canto, argues Mazzoni, means mainly concetto poetico created by the artist's imagination:

Dico ultimemente che quella voce [phantasia] può esser presa per imaginatione nata da oggetto esteriore, et insieme per concetto Poetico senza contradditione. Perché devesi sapere, che il concetto veramente Poetico ha sempre l'origine sua da oggetto fabbricato dall'anima (...).

(Mazzoni 2017: 456)

There is a close similarity between Mazzoni's explication of the category of concetto poetico as a product of phantasia and the definitions of concetto, which appear in the sixteenth and seventeenth century theories of art, primarily in those based on a distorted Platonic concept of the Idea (cf. Panofsky 1968). According to this tradition, concetto is an idea or a 'model' of a work of art formed in the artist's mind and then reproduced (or rather 'represented') in a sculpture, a painting or a poem. In Giorgio Vasari's preface to Lives, disegno is defined as an expression of an idea imagined in the artist's mind — "concetto (...) nella mente imaginato" (Vasari 1568: 43). Earlier, Benedetto Varchi in his lecture on Michelangelo's sonnet Non ba l'ottimo artista in se alcun concetto proves that by concetto Michelangelo means "that form or image, called by some people the intention, that we have within our imagination" ("dentro nella fantasia”, Varchi 1549: 24). In addition, Varchi is convinced (and proves it diligently in Aristotelian terms) that Michelangelo's usage of the word "intelletto" means simply phantasia (Varchi 1549: 30-32; cf. Panofsky 1968: 119-121; Summers 1981: 203-216). Similar thoughts on concetto, closely linked with the faculties of phantasia or imagination, are reiterated by Torquato Tasso and Camillo Pellegrino, Giovan Paolo Lomazzo, and later by Federico Zuccari and Giovan Pietro Bellori. 
Phantasia-imaginatio, therefore, is not only a subsidiary function, but rather an indispensable faculty during the 'embryonic' stage of the process of artistic creation.

From this perspective, Mazzoni's conflation of phantasia and concetto poetico seems rather conventional. But what is more striking and seems highly innovative in his argumentation is his conviction about the intimate connections between poetry and dreams. Interpreting the different meanings of the notion of phantasia, he points to a close affinity between poetic verisimilitude and dreams, arguing that both have their source in imagination: "la Phantasia, è commune potenza dell'anima a'sogni, et al verisimile Poetico" (Mazzoni 2017: 546). The only difference between them is the contribution of the will in the process of constructing concetto poetico and an absence of the will in an involuntary act of dreaming. In a sense, his theoretical intuition (inspired by Aristotle's psychological statements on the role of phantasia in dreams and by Dante's words) precedes the twentieth century insights put forward by Freud or Bachelard.

Mazzoni finishes with a manifest apotheosis of phantasia as a proprium for poetry. He is convinced that only imaginative power enables the poet to create poetic fiction; from this premise, he infers a general conclusion that poetry consists of "fabricated and imagined things":

(...) la Phantasia è la propria potenza delle favole Poetiche, poich' ella sola è capace di quelle fittioni, che da noi stessi possiamo fingere, e fabbricare. A che segue necessariamente, che la Poesia sia di cose finte, et imaginate. Anzi ella è di cose finte, et imaginate, perchè è fondata nella Phantasia. (Mazzoni 2017: 547)

Then, Mazzoni develops his original theory of imitation, reconciling the aspects of fantasy, believability/credibility, possibility, and wonder. As a foundation for this theoretical construction, he uses Aristotle's doctrine of verisimilitude (eikos) from Poetics and a particularly inspiring Aristotelian notion of adunata eikota - 'likely impossibilities' or 'believable impossibilities' which are much more preferred in poetry than unconvincing 'unbelievable possibilities' (dunata apithana) (Poet. 1460a 27). Mazzoni draws on Aristotle's concepts of eikos, 'believable impossibility' and 'wonder' (thaumaston), coming to his own conclusions. His main assumption is that credibile meraviglioso - 'believable wonder' - constitutes the very essence of a work of art (cf. Mazzoni 1578: 403-410; Giglioni 2010: 7-10). There are some hints in his theory of poetic credibility, which foreshadow Coleridge's famous notion of "the willing suspension of disbelief for the moment, which constitutes poetic faith" (Coleridge 1834: 174).

But Aristotelian concepts, though extremely useful as an inspiration for Mazzoni's theory of 'believable wonder', are not enough to satisfy his theoretical ambition and apologetic purpose. To prove that Dante's poem belongs to the highly valued category of poesia phantastica, he refers to the Platonic division of "image-making art" (eidolopoiike techne) into the "likeness-making art" (eikastike techne) and the "fantastic art" (phantastike techne). The distinction between the two types of imitation is established in Plato's Sophist in the discussion on dealing with appearances between Theaetetus and the Stranger from Elea. "Icastic art" deals with likenesses - eikona, which are like the original (but as copies they remain different from the original). "Fantastic art" deals with appearances — phantasmata, which seem to be like the original, but are not, creating only an illusion of likeness from 
a distance (Sophist 235D-236D) ${ }^{6}$. The difference, therefore, is between reality and its representation, between "objectively correct" and "trompe l'oeil imitation" as Erwin Panofsky pointed out in his Idea (1968: 215, n. 51), between likeness and illusion. "Fantastic art" is "viewer relative" (Halliwell 2002: 62) — the effect of the illusion of likeness is achieved thanks to the operation of perspective and depends on an appropriate distance from which the viewer observes the product of phantastike techne. "Icastic" or "assimilative art" - as Marsilio Ficino named it in his commentary to the Sophist — "portrays something according to the model of something that actually exists", ars imaginaria (phantastica) on the contrary — "feigns phantastic simulacra of what do not exist" (Ficino 1989: 268-269).

In Plato's dialogue there is no link between the notion of phantastike techne and the concept of phantasia understood as a faculty, which produces images of non-existent objects. Mazzoni, however, inspired by Ficino's interpretation of the Sophist, makes a strange use of the Platonic notions. He transfers the meanings and interprets Platonic kinds of imitation in terms of the "reproduction of reality" and the "production" of imaginary beings, providing a distorted version of Plato's division. The first kind of "image making art" imitatione icastica is explained by him as an imitation of objects that exist independently and "outside" the artist's mind, while imitatione phantastica relies on the "representation" of objects which exist only within the artist's phantasia. The poet who follows the rules of phantastica imitates the "caprice" (capriccio) of his own fantasy:

(...) l'imitatione può farsi in due modi; il primo de'quali è quando si vanno imitando le cose, che sono fuori del nostro intelletto, (...) Il secondo modo è quando l'Imitatore non rappresenta se non quelle specie, ch'egli ha concette nella sua phantasia. E in questa maniera non imita oggetto porto di fuori, ma solo il capriccio e la phantasia sua. (...) Phantastica è quella che rappresenta i concetti della nostra phantasia, che non hanno certa e ferma corrispondenza colle cose di fuori. (Mazzoni 1587: 394)

The fantastic sort of imitation, which activates the imaginative power, obviously prevails in Mazzoni's theory over "icastic imitation", which consists only in reproduction of copies of existing things. From distorted Platonic concepts mixed with Aristotelian doctrine of poetic eikos, Mazzoni infers the conclusion that the "icastic" kind of imitation is appropriate for a historian rather than for a poet: the true and perfect poet is one who follows "fantastic imitation": "il vero e perfetto Poeta è quello, che prende l'imitatione phantastica" (ibidem 395). Only imitatione phantastica — and Dante's Commedia belongs to this category - is able to reach the very essence of poetry, namely believable wonder credibile meraviglioso.

The manifest appreciation of the "fantastic imitation" and the poet's imaginative activity reconciled with the doctrine of poetic credibility, constitute the most original and distinctive features of Mazzoni's innovative aesthetic project. It is no wonder, therefore, that his theory attracted the curiosity of Renaissance humanists and contributed to the later career of the concept of "fantastic imitation".

The first to follow Mazzoni was Gregorio Comanini who adapted Mazzoni’s doctrine to the theory of painting in his dialogue Il Figino overo del fine della pittura (1591). Comanini

$6 \quad$ For a detailed discussion of the meaning and philosophical implications of Plato's concepts of eikastike and phatastike techne in the Sophist, cf. e.g. Notomi 1999: 246-269; Napolitano Valditara 2007: 165-178; Zawadzki 2007, as well as some interesting remarks by Halliwell 2002: 62-64; 328. 
makes the same use of Platonic distinction from the Sophist, interpreting icastic imitation in terms of reproduction of "things as they are" ("imita le cose, le quali sono"), and fantastic imitation in terms of inventiveness and representation of non-existent objects (“finge cose non esistenti") (Comanini 1591: 28; cf. Comanini 2001). The former category includes painters who represent objects that actually exist in nature, the latter - those who express their own capriccio, which had never been depicted before. Similarly to Mazzoni, Comanini indicates a close link between fantastic imitation and the faculty of imagination ("la virtù fantastica"), which deals with images received from external senses and internal sensus communis - uniting, recomposing and transforming them into new forms (Comanini 1591: 51). For Comanini, the best example of the "fantastic painter" endowed with a "formidable fantasy" ("fantasia gagliardissima") is Giuseppe Arcimboldo - the one who creates marvelous caprices, never seen before and out of the ordinary images, ingeniously and arbitrarily joining together elements which could seem impossible to reconcile.

Comanini's theory shows explicitly that at the end of Renaissance, Plato's notion of phantastike techne had completely lost its original meaning of 'trompel'oeil imitation' and had been radically transformed becoming a useful argument for all 'apologists' of imagination. For this reason, when Franciscus Junius composes his theory of painting in the first half of the seventeenth century, he can call upon Plato's authority to confirm his thesis on the importance of the painter's imagination. And in his version as well, phantastike techne is interpreted as an "expression" of objects formed by fantasy:

So doth then this same most fertile power of our soule [imagination], according to Plato his opinion, yeeld two sorts of Imitation: the first medleth onely with things seene, whilest they are set before eyes; the other on the contrary studieth also to expresse things prefigured only and represented by the phantasie. (Junius 1638: 18-19)

However, not all of the Renaissance humanists were as prone as Comanini to accept Mazzoni's erroneous interpretation of Plato's notion of fantastic imitation. Mazzoni's most acute adversary was Francesco Patrizi, the vanguard author of "aesthetics of marvelous", who rejected the traditional Aristotelian equivocation between poetry and mimesis. He correctly interprets Plato's distinction between the two kinds of imitation and points out Mazzoni's misinterpretation. Patrizi is very close to Plato's thought when he argues that both eikastike techne and "fantastic imitation" should be understood as production of images (idol) — or similar to the model ("icone cioè la effigie vera", or appearance ("immagine apparente") — and both "have their ontological counterpart in the reality outside the mind" (Giglioni 2010: 11; Patrizi 1969: 78-82; 1970: 278). Although Patrizi mocks Mazzoni's reading of phantastike techne in terms of activity of imagination, he is far from disapproving the very concept of phantasia and its role in poetry, yet he does not treat imagination as the only and most important faculty that participates in the process of creation of poetic wonder (meraviglia) (cf. Patrizi 1970: 360).

Another adversary is Torquato Tasso, an advocate of "icastic imitation", who protests against Mazzoni's definition of poetry as a kind of sophistic art. Such 'sisterhood' between poetry and sophistry is totally unacceptable in his poetics. In consequence, he rejects the belief that the phantastic is the most perfect kind of imitation, as it represents "what does not exist", namely falsehood, while true poetry — and here Tasso calls upon 
Aristotle's Poetics — should deal with things that "are, were, or may be". For Tasso, poetry belongs rather to the category of dialectic and the poet, though he is a maker of images (idoli), is more like a dialectician or a theologian than a deceitful sophist (Tasso 1964: 86-89). Tasso's argumentation concerning poetic truth and falsehood is elaborate and very consistent, therefore as a defender of 'true' icastic poetry he cannot concede with Mazzoni that poetry is the 'product' of mere phantasia - the faculty of the sensitive soul, which is not an intellective power (virtù intellettiva). That is why, by mixing the Aristotelian definition of phantasia from De Anima (3.3) with Neoplatonic thought, he establishes a differentiation between simple fantasy and its higher form - fantasia intelettuale that has an access to the intelligible (Tasso 1964: 90-91). Only the latter type of imagination plays a significant role in "true poetry" and therefore Tasso argues that Dante's expression alta fantasia should be read precisely in the sense of "intellectual imagination" (imaginazione intellettuale).

The dual imagination theory that discriminates between phantasia and its more noble version imaginazione intellettuale has its beginnings in a long tradition rooted in Avicenna's division between two kinds of 'imagination' - sensory, receptive imaginatio (that only receives and preserves 'images' obtained from sensus communis) and deliberative, active vis imaginativa (Avicenna 1546: 13r-14r; cf. Kemp 1977: 362; Russo 2002: 200-230). But Tasso's theory of 'intellectual imagination' with its context requires a separate study. What is important at this point is the fact that despite his rejection of Mazzoni's apotheosis of "fantastic imitation" he does not refute the thesis about the importance of imagination in the process of artistic creation. This is consistent with the view he expressed in his letters, namely that the poet needs a "strong imagination" (imaginazione gagliarda) (Tasso 1804: 260). In his argument with Mazzoni, Tasso develops the theory of phantasia providing a highly intellectualized concept of imagination.

In the case of Philip Sidney's theory of creative imitation one could expect that the notion of "fantastic imitation" - similar to the one proposed by Mazzoni — would appear in his Apology, yet Sidney's statements are more akin to Tasso's. However, unlike Mazzoni and Tasso, he associates imitation with the power of wit (the concept whose vast meaning embraces both faculties — reason and imagination), and not explicitly with the faculty of phantasia. Sidney correctly interprets Platonic notions of icastic and fantastic art and remains a skeptic about the deceitful phantastica, "which doth infect the fancy with unworthy objects; as the painter, that should give to the eye either some excellent perspective, or some fine picture (...)" (Sidney 2002: 104).

Despite more or less manifest differences between Renaissance theorists' opinions on the category of "fantastic imitation", it is unquestionable that at the end of the sixteenth century their position towards imagination shows evident appreciation. Sometimes there is a subtle ambivalence as in the case of Tasso and Sidney, whose theories reveal a mixture of attraction and resistance towards the possibly deceitful phantasia or "fantastic imitation". Sometimes it is a profound fascination as in the case of Mazzoni and Comanini. Renaissance theorists were convinced that phantasia-imaginatio plays an important role in the process of artistic creation - either as a faculty responsible for creating non-existent, imaginative beings, or as an intellective capacity that reaches the intelligible. Moreover as clearly shown in the theory of concetto - imagination's activity was absolutely indispensable during an internal act of cogitation when an idea (concetto) or disegno is formed in the 
artist's mind. Imagination is the source of internal creativity, though obviously it is not the only 'architect' of the work of art that freely and arbitrarily determines all its features. Phantasia cooperates with other internal senses - with memory and cogitatio, then with intellect and reason. But this necessary relationship between imagination and the higher intellective powers does not involve its absolute subordination to reason in the act of creation - rather it is a reciprocal interrelation: "without fantasy the intellect would be blind", as one of the seventeenth century theorists summarizes (Tesauro 1670: 26).

Although, some 'subconscious' associations with Romantic thought are inescapable, when one touches upon the question of 'creative' imagination, a complex parallel between early modern and Romantic views of imagination is an open question for future studies. The sixteenth century reflections described above constitute the Renaissance aesthetics of phantasia and confirm the significance of the concept of imagination at that time. However, at this point, an attempt to briefly juxtapose them with the eighteenth century theories of imagination would run the risk of superficiality and oversimplification. Therefore, in the spirit of Renaissance poetics of phantasia, rather than a strictly academic conclusion, it will be enough to imagine the following 'possibilities': If Jacopo Mazzoni had been writing his Difesa at the end of the eighteenth century, he would not have needed to reconcile fictional poetic impossibilities with the believable. Had Philip Sidney defended poetry at the same time, he certainly would have used the word "imagination" instead of "wit" or mere "invention". If Torquato Tasso had ever read Coleridge's Biographia Litteraria, he would have cherished the distinction between fantasy and imagination. Had Francesco Patrizi, in turn, studied the same text, he would have been surely surprised that Coleridge describes the word "esemplastic" (coined from Greek " $ı \iota \varsigma \varepsilon \nu ~ \pi \lambda \alpha \tau \tau \varepsilon \nu$ " in order to illustrate the unifying power of imagination) as his own invention. For it was Patrizi who at the end of the sixteenth century made comparably ingenious use of the Greek word "plattein" to describe the active process of artistic creation, which he understood as the unification of heterogeneous concepts and images (Patrizi 1971: 19). Coleridge would simply say: "esemplastic" — "to shape into one" (Coleridge 1834: 97). 


\section{Bibliography}

Armisen Mireille (1979), La notion d'imagination chez les Anciens. I: Les philosophes, „Pallas” 26, $11-51$.

- (1980), La notion d'imagination chez les Anciens. II: La rhétorique, „Pallas” 27, 3-37.

Avicenna (1546), Compendium de anima ab Andrea Alpago Bellunensi philosopho ac medico, idiomatisque arabici peritissimo ex arabico in latinum versa, Venetiis, apud Iuntas.

Bulgarini Bellisario (1583), Alcune considerazioni sopra il Discorso di M. Giacopo Mazzoni, fatto in Difesa della Comedia di Dante, stampato in Cesena l'anno 1573, apresso Luca Bonetti, Siena.

Castravilla (1608), Discorso di M. Ridolfo Castravilla nel quale si mostra l'imperfettione della Commedia di Dante [in:] Bulgarini Belissario, Annotazioni ovvero chiose marginali di Belissario Bulgarini... sopra la prima parte della Difesa, fatta da M. Iacopo Mazzoni..., Aggiontovi il Discorso di M. Ridolfo Castravilla sopra la medesima Commedia, Siena.

Chevrolet Teresa (2007), L’idée de fable. Théories de la fiction poétique à la Renaissance, Librairie Droz, Genève.

Cocking John M. (1991), Imagination. A Study in a History of Ideas, ed. P. Murray, Routledge, London-New York.

Coleridge Samuel Taylor (1834), Biographia Litteraria or Biographical Sketches of My Literary Life and Opinions, Leavitt, Lord \& Co., New York.

Comanini Gregorio (1591), Il Figino overo del fine della pittura. dialogo del rever. padre D. Gregorio Comanini Canonico Regolare Lateranese. Ove quistionandosi, se'l fine della pittura sia l'utile overo il diletto, si tratta dell'uso di quella nel Christanesimo e si mostra, qual sia imitator più perfetto, \& che più diletti, il Pittore, overo il Poeta, per Francesco Osanna, Mantova.

De la phantasia à l'imagination (2003), eds. D. Lories et L. Rizzerio, Société des Études Classiques, Namur.

Faivre Antoine (1981), L'imagination creatrice. (Fonction magique et fondement mythique de l'image), "Revue d'Allemagne" 3, no 2.

Ficino Marsilio (1576), Marsilii Ficini Florentini, translatio simul \& explanatio in Prisciani Lydi interpretationem super Theophrastum de phantasia \& intellectu [in:] idem, Opera, ex officina Henricpertina, Basileae.

- (1987), El libro dell'amore, ed. S. Niccoli, Olschki Editore, Firenze.

- (1989), Commentaria in Platonis Sophistam [in:] M.J.B. Allen, Icastes: Marsilio Ficino's Interpretation of Plato's „Sophist”, University of California Press, Berkeley.

Gigante Claudio (2001), Per un'edizione critica 'Della Difesa della Commedia di Dante' di Jacopo Mazzoni, „Rivista di Studi Danteschi” 1.

- (2003), Esperienze di filologia cinquecentesca: Salviati, Mazzoni, Trissino, Costo, Il Bargeo, Tasso, Salerno, Roma.

Giglioni Guido (2010), The Matter of Imagination. The Renaissance Debate over Icastic and Fantastic Imitation, „Camenae” 8, p. 1-21.

Halliwell Stephen (2002), The Aesthetics of Mimesis. Ancient Texts and Modern Problems, Princeton UP, Princeton-Oxford.

Hathaway Baxter (1962), The Age of Criticism. The Late Renaissance in Italy, Cornell UP, ItacaNew York.

Imago in phantasia depicta'. Studi sulla teoria dell'immaginazione (1999), ed. L. Formigari, G. Casertano, Carocci, Roma. 
Junius Franciscus (1638), The Painting of the Ancients in Three Bookes, Declaring by Historical Observations and Examples... written first in Latin by Franciscus Junius and now by him Englished with some additions and alterations, printed by Richard Hodkinsonne, London.

Kemp Martin (1977), From "mimesis” to ,fantasia”: The Quattrocento Vocabulary of Creation, Inspiration and Genius in the Visual Arts, „Viator” 8.

La Primaudaye Pierre de (1580), Suite de l'Academie francoise, en laquelle il est traicté de l'homme et comme par une histoire du corps et de l'âme, Paris.

Manieri Alessandra (1998), L’immagine poetica nella teoria degli antichi. Phantasia ed enargeia, Istituti Editoriali e Poligrafici Internazionali, Pisa-Roma.

Mazzoni Jacopo (1587), Della Difesa della „Comedia“ di Dante distinta in sette libri, nella quale si risponde alle oppositioni fatte al Discorso di M. Iacopo Mazzoni, e si tratta pienamente dell'arte poetica e di molt'altre cose pertenenti alla philosophia \& alle belle lettere (parte prima che contiene i primi tre libri con due tavole copiosissime), Cesena.

- (2017), Della difesa della "Comedia" di Dante, eds. C. Moreschini, L. Businarolo, Società di Studi Romagnoli, Cesena.

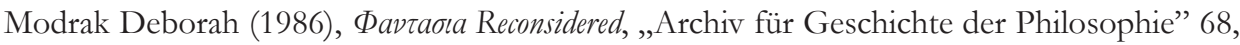
p. 47-69.

Moreschini Claudio (2016), Idolo, fantasia e poesia da Ficino a Mazzoni, "Bruniana \& Campanelliana" 22, no 1.

Napolitano Valditara Lidia M. (2007), Platone e le ragioni dell'immagine. Percorsi filosofici e deviazioni tra metafore e miti, Vita e Pensiero, Milano.

Notomi Noburu (1999), The Unity of Plato's "Sophist". Between the Sophist and the Philosopher, Cambridge UP, Cambridge.

Panofsky Erwin (1968), Idea. A Concept in Art Theory, trans. J.J.S. Peake, University of South Carolina Press, Columbia.

Patrizi Francesco (1970), La deca ammirabile, La deca disputata [in:] idem, Della poetica, vol. 2, ed. D. Aguzzi Barbagli, Firenze.

- (1971), La deca plastica [in:] idem, Della poetica, vol. 3, ed. D. Aguzzi Barbagli, Firenze.

Phantasia-imaginatio (1988), V Colloquio Internazionale Roma 9-11 Gennaio 1986, Atti eds. M. Fattori, M. Bianchi, Lessico Intelettuale Europeo XLVI, Roma.

Puttenham George (2007), The Art of English Poesy by George Puttenham. A Critical Edition, ed. F. Whigham, W.A. Rebhorn, Cornell University Press, Ithaca-London.

Rispoli Gioia Maria (1985), L'artista sapiente. Per una storia della fantasia, Liguori Editore, Napoli. Ronsard Pierre de (1870), Abbregé de l'art poétique françois [in:] Oeuvres choisies, avec notice, notes et commentaires par C.A. Sainte-Beuve, nouvelle édition, revue et augmentée par M.L. Moland, Garnier, Paris.

Russo Emilio (2002), L'oridne, la fantasia e l'arte. Ricerche per un quinquennio tassiano (1588-1592), Bulzoni Editore, Roma.

Scarpati Claudio (1985), Iacopo Mazzoni fra Tasso e Marino, „Aevum” 59.

- (2002), 1585-1587: Tasso, Patrizi e Mazzoni, „Aevum” 76.

Sheppard Anne (2014), The Poetics of Phantasia. Imagination in Ancient Aesthetics, Bloomsbury, London.

Sidney Philip (2002), An Apology for Poetry or The Defence of Poesy, ed. G. Shepherd, revisited and expanded for third edition by R.W. Maslen, Manchester UP, Manchester-New York. 
Starobinski Jean (1970), Jalons pour une histoire du concept d'imagination [in:] idem, L'oeil vivant II, Gallimard, Paris.

Summers David (1981), Michelangelo and the Language of Art, Princeton UP, Princeton.

Tasso Torquato (1804), Lettere [in:] idem, Opera, vol. 3, dalla Società Tipografica de'Classici Italiani, Milano.

- (1859), I Dialoghi, a cura di Cesare Guasti, vol. III, Le Monnier, Firenze.

- (1964), Discorsi dell'arte poetica e del poema eroico, ed. L. Poma, Gius. Laterza \& Figli (Scrittori d'Italia N. 228), Bari.

Tesauro Emanuele (1670), La filosofia morale derivata dall'alto fonte del grande Aristotele Stagirita, Bartolomeo Zapata, Torino.

Tomitano Bernardino (1570), Quattro libri della lingua toscana, ove si prova la philosophia esser necessaria al perfetto oratore \& poeta, Marcantonio Olmo, Padova.

Varchi Benedetto (1549), Due lezioni di M. Benedetto Varchi nella prima delle quali si dichiara un sonetto di M. Michelangelo Buonarotti. Nella seconda si disputa quale sia piu nobile arte, la scultura o la Pittura, Lorenzo Torrentino, Fiorenza.

Vasari Giorgio (1568), Le Vite de piu eccellenti architetti, pittori, et scultori italiani da Cimabue insino a'tempi nostri, descritte in lingua toscana, da Giorgio Vasari Pittore Aretino, con una sua utile \& necessaria introduzione e le arti loro, Primo volume della terza parte, I Giunti, Fiorenza.

Watson Gerard (1988), Phantasia in Classical Thought, Galway UP, Galway.

Weinberg Bernard (1961), A History of Literary Criticism in the Italian Renaissance, vol. 1-2, Chicago UP, Chicago.

Wels Volkhard (2005), Zur Vorgeschichte des Begriffs der 'Kreativen Phantasie', "Zeitschrift für Ästhetik und allgemeine Kunstwissenschaft" 50, no 2.

Wolfson Harry Austryn (1973), Studies in the History of Philosophy and Religion, vol. I, Harvard UP, Cambridge.

Wordsworth William (1850), The Prelude, or Growth of a Poet's Mind: An Autobiographical Poem, Edward Moxon, London.

Zawadzki Andrzej (2007), 'Symploke’ jako figura Platońskiej mimesis, „Wielogłos” 1, nr 1. 